soy and corn in foodstuffs. Over the past 12 months the company has made significant efforts to license its test protocols to European laboratories.

At the end of 1996, for instance, Dutch government officials had claimed that requirements to label genetically engineered foods could not be satisfied because testing was not technically possible. What that meant, said one observer, was that the TNO laboratory - the de facto Dutch government reference analytical laboratory-had not itself developed a test. In December 1996, however, TNO became a nonexclusive licensee of Genetic ID's test and offered the testing service. According to Gert van Duijn, who heads TNO's genetic testing services, the agreement with Genetic ID was short-lived, ending in March or April 1997.

The reasons for the split are not entirely clear but are in part related to Genetic ID's political connections. Hagan is a prominent member of the Natural Law Party, an organization whose US presidential candidate, John Hagelin, has written and spoken extensively about the "hazards of genetically engineered foods." Hagan shares that stance. He is a molecular biologist at Maharishi University of Management (Fairfield, IA), and is perhaps best known for returning a US National Institutes of Health (Bethesda, MD) grant of $\$ 613,882$ in 1994 to protest against what he considered inadequate safeguards in the genetic engineering field. "I don't make any bones about my concerns," he says. But he claims he maintains a strict separation between his activist agenda and his work for Genetic ID.
For TNO, however, the Natural Law Party connections were "not a positive aspect" of Genetic ID, according to Gert van Duijn. TNO has now developed and is selling its own tests.

GenoLife, another early Genetic ID licensee, started to offer testing for genetically engineered food ingredients at the end of 1996. The company's operations manager, Franck

\section{IMAGE UNAVAILABLE FOR COPYRIGHT REASONS}

Food containing Monsanto's Roundup Ready soybeans may soon be flagged in testing.

Chaubron, has no problem with Genetic ID's political provenance. "It's a good test," he says. "We are only doing business with Genetic ID. We have no political motivation." Although Genetic ID is still looking for other European licensees-it approached the UK's Leatherhead Food Research Association (Leatherhead, UK) just after its relationship with TNO ended-none of the other testing companies have entered licensing agreements.

Genetic ID's PCR-based assay is among the most stringent and, at around $\$ 470$, is the most expensive of the tests available. DNA is extracted from a food sample by a guanidinium isothiocyanate method that denatures DNases. Four PCR reactions are then run, each employing a different primer set. A control set covers sequences that are present naturally in the applicable crop The other primer sets are specific for three different domains in the recombinant genes that have been inserted into soybeans or corn. Genetic ID labels a sample positive only if it detects a clear signal with all three primer sets.

Although Genetic ID claims that this protocol could detect 1 transgenic soybean out of 10,000 , the company has now calibrated it at a more practical ratio of 1 in 1,000. For more complex foods, Fagan figures that the assay will work if at least $5 \%$ of a product's weight consists of relatively unprocessed soybean.

According to the genetic testing companies, their clients are largely food importers, exporters, and processors. Jorgensen says that most of Genetic ID's customers are in Europe and Japan. Its American clients, unlike those in other countries, tend to be in the natural and organic food industry. But although concern over transgenic food isn't widely felt in the United States, some groups are still hoping for a cause célèbre. In a petition filed last September, Greenpeace and 32 other organizations alleged that the US Environmental Protection Agency (EPA; Washington, DC) seriously threatened humans and the environment by approving Bacillus thuringiensisexpressing plants. The groups essentially want to stop the sale of seeds for these plants. The EPA must respond to the petition this month.

Douglas Steinberg

\title{
Rhône-Poulenc rounds up DeKalb and Monsanto
}

Rhône-Poulenc Agro (Research Triangle Park, NC and Lyon, France) filed a lawsuit at the end of October against DeKalb Genetics (Dekalb, IL) and Monsanto (St. Louis, MO), claiming that they are misusing its genetically engineered materials in herbicide-resistant Roundup Ready corn, which the two companies plan to begin marketing in 1998. However, according to DeKalb and Monsanto, licensing agreements between DeKalb and Rhône-Poulenc, as well as a 1994 settlement of an earlier lawsuit concerning these technologies, "clearly permits DeKalb to commercialize Roundup Ready corn."

Rhône-Poulenc claims that DeKalb and Monsanto not only overstepped a licensing agreement between Rhône-Poulenc and DeKalb, but are also infringing on two Rhône-Poulenc patents-US 5,510,471 and $5,633,448$, which describe genes for glyphosate-tolerance and optimized transit peptides as well as their uses in genetically engineered corn.
"Our 1994 agreement with DeKalb gave them the right to license with contract breeders, but was never extended to Monsanto," says Rhône-Poulenc spokesman Rick Rountree. Subsequent to that agreement, early in 1996 DeKalb and Monsanto established a biotechnology research collaboration and also signed three cross-licensing agreements covering insect- and herbicide-resistant corn. Now, according to Rhône-Poulenc, Monsanto is "attempting to transfer our technologies to its subsidiaries," and is also tying up "corn-seed markets." Hence the lawsuit, with which Rhône-Poulenc is seeking "recognition of. . .[its] ownership of the biotechnology innovations in question," and also "some profit-sharing arrangement with anyone who chooses to utilize our genetic technology."

"It's our belief the [Rhône-Poulenc] lawsuit is frivolous and has no merit," says Monsanto spokesman Dan Homan. "As we're ready to go to market, they're trying to redo the 1994 deal that, in very broad language, gave DeKalb rights to this technology along with rights to sublicense it."

"Language contained in DeKalb's 1994 agreement with Rhône-Poulenc was specifically designed to facilitate the commercialization of glyphosate-resistant corn," says DeKalb chairman and CEO Bruce Bickner. $\mathrm{He}$ insists that the agreement "gives DeKalb the right to grant sublicenses to any third party." It also "contains no limitations whatsoever on DeKalb's right to use the [Rhône-Poulenc] technology and genetic material in corn."

Meanwhile, DeKalb has been zealously defending its intellectual property rights over genetically modified corn. Among other actions, DeKalb also has sued Northrup King (Minneapolis, MN), Beck's Hybrids (Atlanta, IN), and Countrymark (Indianapolis, IN) over alleged infringements of patents on Bacillus thuringiensis pest-resistant corn.

Jeffrey L. Fox 